\title{
Analisis Medan Magnet Terhadap Operator yang Bekerja pada Saluran Transmisi Menggunakan Metode Elemen Hingga
}

\author{
Aditya Dwinugraha, I Made Yulistya Negara, dan Arif Musthofa \\ Jurusan Teknik Elektro, Fakultas Teknologi Industri, Institut Teknologi Sepuluh Nopember (ITS) \\ Jl. Arief Rahman Hakim, Surabaya 60111 \\ e-mail: yulistya@ee.its.ac.id, arif@ee.its.ac.id
}

\begin{abstract}
Abstrak-Pemakaian tegangan tinggi selain untuk mengurangi rugi-rugi daya, juga menghasilkan medan magnet di sekitar kawat penghantar. Medan magnet di sekitar kawat penghantar menimbulkan dampak merugikan bagi operator maupun penduduk yang bertempat tinggal di dekat saluran transmisi Untuk menganalisis distribusi medan magnet pada saluran transmisi di gunakan perangkat lunak berbasis FEM (Finite Element Methode). Ide dasar dari FEM adalah membagi struktur, badan (body), atau daerah yang dianalisis menjadi jumlah yang sangat besar dari suatu elemen hingga (finite element). Oleh karena itu, dalam penelitian ini akan mensimulasikan saluran transmisi $500 \mathrm{kV}$ dan pengaruhnya terhadap sekitar (operator) untuk mendapatkan medan magnet yang di hasilkan. Penelitian ini akan menggunakan perangkat lunak CST Studio berbasis FEM untuk melakukan simulasi distribusi medan magnet yang di hasilkan oleh saluran transmisi dan terhadap manusia.
\end{abstract}

Kata Kunci-CST Studio, Finite Element Method, Medan Magnet, Menara Transmisi, Saluran Transmisi.

\section{PENDAHULUAN}

$\mathrm{E}$ NERGI listrik adalah salah satu energi yang sangat diperlukan dalam kehidupan sehari hari, sebelum dapat kita gunakan energi listrik dibangkitkan dari berbagai macam sumber seperti PLTA (Pembangkit Listrik Tenaga Air), PLTU (Pembangkit Listrik Tenaga Uap), dan PLTG (Pembangkit Listrik Tenaga Gas) setelah itu energi listrik tegangannya di naikan oleh trafo step up dan disalurkan melalui saluran transmisi hal ini bertujuan untuk memperkecil rugi daya dan susut tegangan pada saluran transmisi, setelah itu tegangan diturunkan menggunakan trafo step down lalu disalurkan melalui saluran distribusi hingga dapat kita gunakan.

Fungsi utama suatu saluran transmisi adalah untuk menyalurkan energi listrik dari pusat pembangkit ke pusatpusat beban. Untuk mengurangi rugi - rugi daya disepanjang saluran transmisi, maka dipakailah tegangan tinggi. Pemakaian tegangan tinggi ini selain mengurangi rugi-rugi daya, juga menghasilkan medan magnet di sekitar kawat penghantar [1]. Medan magnet di sekitar kawat penghantar menimbulkan dampak merugikan bagi operator maupun penduduk yang bertempat tinggal di dekat saluran transmisi

Untuk menganalis distribusi medan magnet pada saluran transmisi akan digunakan metode yang bernama FEM (Finite Element Method). [2,5].

Pada studi kali ini, simulasi menggunakan CST Studio berbasis Finite Element Method (FEM) digunakan untuk mengetahui kondisi dan persebaran medan magnet pada saluran transmisi $500 \mathrm{kV}$ dan seberapa besar bahayanya terhadap operator.

\section{PERHITUNGAN MEDAN MAGNET PADA SALURAN TRANSMISI}

Dalam kalkulasi medan magnet, kekuatan medan magnet $(\mathbf{H})$ membawa serangkaian informasi yang terdiri dari medan magnet $(\mathbf{B})$ yang dimana $\mathbf{B}=\mu \mathbf{H}$. Pemanfaatan persamaan gelombang (Helmholtz's equation) ada di (1)[5]. Ketika sumber frekuensi adalah $50 \mathrm{~Hz}$, medan magnet memodelkan hukum persamaan arus yang terdefinisi sebagai berikut.

$$
\frac{\partial^{2} \mathrm{H}}{\partial \mathrm{x}^{2}}+\frac{\partial^{2} \mathrm{H}}{\partial \mathrm{y}^{2}}+\frac{\partial^{2} \mathrm{H}}{\partial \mathrm{z}^{2}}-\varepsilon \mu \frac{\partial^{2} \mathrm{H}}{\partial \mathrm{t}^{2}}-\mu \sigma \frac{\partial \mathrm{H}}{\partial \mathrm{t}}=0
$$

Dimana, $\mu$ adalah permeabilitas magnet, $\sigma$ adalah konduktivitas, dan $\varepsilon$ adalah konstanta permitivitas dielektrik.

Dengan mempertimbangkan sistem harmonik waktu yang menyatakan $\mathbf{H}=H e^{j \omega t}$, maka

$$
\frac{\partial^{2} H}{\partial x^{2}}=-\omega^{2} H \quad \text { dan } \quad \frac{\partial H}{\partial t}=j \omega H
$$

Dimana $\omega$ adalah frekuensi angular

Oleh karena itu, melihat dari persamaan 3.1 dapat menjadi persamaan sebagai berikut.

$$
\nabla^{2} \mathrm{H}-\mathrm{j} \omega \sigma \mu \mathrm{H}+\omega^{2} \varepsilon \mu \mathrm{H}=0
$$

Dengan mempertimbangan masalah di 3 dimensi $(x, y, z)$, maka

$$
\frac{\partial}{\partial x}\left(\frac{\partial H}{\partial x}\right)+\frac{\partial}{\partial y}\left(\frac{\partial H}{\partial y}\right)+\frac{\partial}{\partial z}\left(\frac{\partial H}{\partial z}\right)-\left(j \omega \mu \sigma-\mu \varepsilon \omega^{2}\right) H=0
$$

\section{METODE PERHITUNGAN MEDAN MAGNET DENGAN METODE ELEMEN HINGGA}

\section{A. Metode Element Hingga (FEM)}

Metode elemen hingga merupakan salah satu metode numerik yang sering digunakan untuk menyelesaikan permasalahan struktur, termal dan elektromagnetik. Dalam metode ini permasalahan diselesaikan dengan menggunakan pendekatan prinsip dasar proses diskretasi. Proses diskretisasi pada elemen hingga adalah proses pembagian pada pemodelan struktur objek dengan membaginya dalam elemen-elemen kecil yang jumlahnya tidak terbatas tergantung objek tersebut [1,2]. Elemen-elemen tersebut adalah bentuk mesh-mesh kecil yang terdapat pada obyek tersebut. Metode perhitungannya adalah menghitung mesh- 
mesh kecil yang nantinya digabung menjadi suatu bentuk yang lebih besar untuk digabungkan. Hasil yang didapatkan berasal dari nilai pendekatan yang kontinyu terhadap yang berhubungan antar bagian meshnya sehingga menjadi bentuk yang diharapkan[5,8].

\section{B. Perhitungan Medan Magnet pada Saluran Transmisi}

Metode umum untuk perhitungan medan magnet disekitar transmisi dapat dihitung dengan menggunakan analisis 2 dimensi. Dengan menggangap bahwa transmisi sejajar dengan permukaan bumi yang datar. Dengan menggunakan sistem koordinat yang diuraikan seperti gambar dibawah ini.

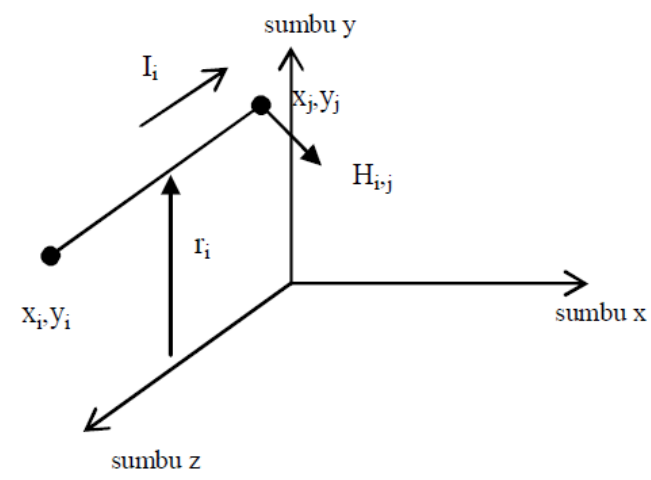

Gambar 1. Sistem Koordinat Perhitungan

Pada gambar 3.1, digambarkan bahwa konduktor transmisi sejajar dengan sumbu Z. Konduktor membawa arus sebesar $\mathrm{I}_{\mathrm{i}}$, dengan arah berlawanan sumbu $\mathrm{Z}$.

Arah kuat medan $\mathrm{H}_{\mathrm{ji}}$ pada titik $\mathrm{x}_{\mathrm{j}} \cdot \mathrm{y}_{\mathrm{j}}$ dengan jarak $\mathrm{r}_{\mathrm{ij}}$ dari permukaan bumi mempunyai amplitudo

$$
\mathrm{H}_{\mathrm{j} . \mathrm{i}}=\frac{\mathrm{I}_{\mathrm{i}}}{2 \pi \mathrm{r}_{\mathrm{i} . \mathrm{j}}}
$$

Dalam nitasi vektor dituliskan

$$
H_{j . i}=\frac{I_{i} \times r_{j . i}}{2 \pi r_{i . j}^{2}}=\frac{I_{i}}{2 \pi r_{i . j}} \Phi_{i . j}
$$

Unit vektor arah $\Phi_{i . j}$

$$
=-\frac{y_{i}-y_{j}}{r_{i j}} u_{x}+\frac{x_{i}-x_{j}}{r_{i j}} u_{y}
$$

Dimana $\mathrm{u}_{\mathrm{x}}=$ unit vektor arah sejajar sumbu $\mathrm{x}$ dan $\mathrm{u}_{\mathrm{y}}=$ unit vektor arah sejajar sumbu y.

Jika ada beberapa konduktor yang membawa arus listrik maka kuat medan totalnya menjadi

$$
\mathrm{H}_{\mathrm{ji}}=\Sigma \frac{\mathrm{I}_{\mathrm{i}}}{2 \pi \mathrm{r}_{\mathrm{i} . \mathrm{j}}} \Phi_{\mathrm{i} . \mathrm{j}}
$$

Medan magnet disekitar transmisi 3 fasa dipengaruhi oleh kehadiran arus balik tanah (earth return) khususnya untuk titik yang jauh dari transmisi (dan dekat dengan tanah). Untuk transmisi yang seimbang, arus ini terdistribusi melalui tanah sepanjang transmisi, meskipun akhirnya jumlah arusnya adalah nol. Arus tanah dapat dihitung dengan rumus Carson. Dengan demikian kuat medan magnet yang dihasilkan oleh transmisi dan arus tanah dapat dituliskan [6]

$$
\mathrm{H}_{\mathrm{ji}}=\frac{\mathrm{I}_{\mathrm{i}}}{2 \pi \mathrm{r}_{\mathrm{i} . \mathrm{j}}} \Phi_{\mathrm{i} . \mathrm{j}}-\frac{\mathrm{I}_{\mathrm{i}}}{2 \pi \mathrm{r}_{\mathrm{i} . \mathrm{j}}^{\prime}}\left[1+\frac{1}{3}\left(\frac{2}{\gamma \mathrm{r}_{\mathrm{i} . \mathrm{j}}^{\prime}}\right)^{4}\right] \Phi_{i . j}^{\prime}
$$

Persamaan 3.8 menunjukkan medan magnet akibat pengaruh transmisi, sedangkan persamaan 3.9 menunjukkan medan magnet akibat pengaruh arus balik di bumi yang juga merupakan faktor koreksi karena arus balik tanah sebesar $\gamma=$ $[j \omega \mu(\sigma+j \omega \varepsilon)]^{1 / 4}$

Keterangan:

$\sigma=$ konduktivitas tanah $(0,001$ sampai dengan $0,002 \mathrm{~S} / \mathrm{m})$

$\varepsilon=$ permitivitas tanah $\left(8,85.10^{-12}\right.$ sama dengan permitivitas udara)

terlihat bahwa $r^{\prime}{ }_{i j}$ juga merupakan bilangan komplek

$$
r_{i . j}^{\prime}=\left[\left(x_{i}-x_{j}\right)^{2}+\left(y_{i}-y_{j}+2 / \gamma\right)^{2}\right]^{1 / 4}
$$

Sedangkan

$$
\Phi_{i . j}^{\prime}=-\left[\frac{y_{i}-y_{j}+2 / \gamma}{r_{i j}^{\prime}}\right] u_{x}+\frac{x_{i}-x_{j}}{r_{i j}^{\prime}} u_{y}
$$

Dari rumus diatas terlihat bahwa kuat medan magnet $\mathrm{H}$ tidak akan sefasa dengan sumber arusnya bila efek arus bumi diperhitungkan.

\section{Perhitungan Medan dan Penyatuan Element Segitiga}

Inti dari metode elemen hingga adalah diskretisasi, yaitu pembentukan mesh elemen-elemen segitiga kecil dengan jumlah yang tak terbatas. Dengan mengetahui nilai potensial (V) pada satu elemen segitiga maka akan didapat nilai medan listrik pada permukaan isolator tersebut.

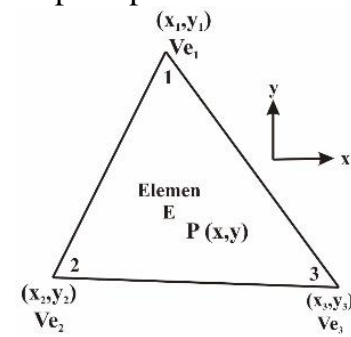

Gambar 2. Pemodelan bentuk elemen segitiga

Persamaan mencari energi pada medan elektrostatik untuk tiap elemen dapat didapatkan dari fungsi berikut:

$$
W_{E}=\frac{1}{2} \varepsilon_{0} \varepsilon_{r} V^{T} S V
$$

Berikut metode penyatuan elemen-elemen segitiga yang telah terbentuk.

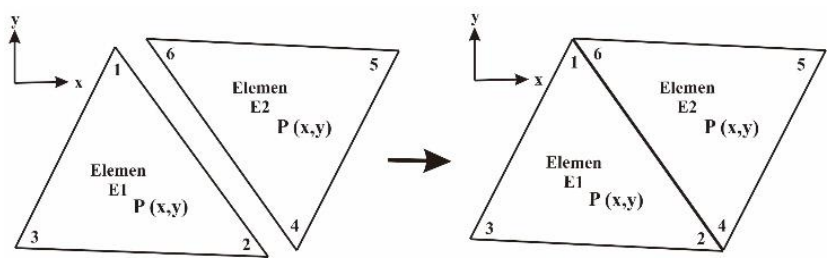

Gambar 3. Penggabungan dua elemen segitiga

Dari penggabungan beberapa elemen segitiga tadi didapatkan nilai energinya :

$$
W=\frac{1}{2} \varepsilon_{0} \varepsilon_{r} V_{c o n}^{T} S V_{\text {con }}
$$

Dimana

$$
S=C^{T} S_{d i s} C
$$


Persamaan (18) dapat dijabarkan menjadi suatu matrik koefisien yang terhubung antar satu segitiga dengan yang lainnya. Matriks koefisiensi dari pengabungan dua element segitiga seperti pada gamba dibawah ini :

$S=\left[\begin{array}{llllcc}S_{11}^{(1)}+ & S_{66}^{(2)} & S_{12}^{(1)}+ & S_{64}^{(2)} & S_{13}^{(1)} & S_{65}^{(2)} \\ S_{21}^{(1)}+ & S_{46}^{(2)} & S_{22}^{(1)}+ & S_{44}^{(2)} & S_{23}^{(1)} & S_{45}^{(2)} \\ S_{31}^{(1)} & & S_{32}^{(1)} & & S_{33}^{(1)} & 0 \\ S_{56}^{(1)} & & S_{54}^{(1)} & & 0 & S_{55}^{(2)}\end{array}\right]$

(15)

\section{Pemodelan Tower, Isolator, dan Manusia}

Pemodelan awal yang dilakukan adalah pemodelan tower transmisi. Jenis tower yang digunakan dalam pemodelan adalah suspension tower. Hasil pemodelan tower transmisi dapat dilihat pada gambar 4 .

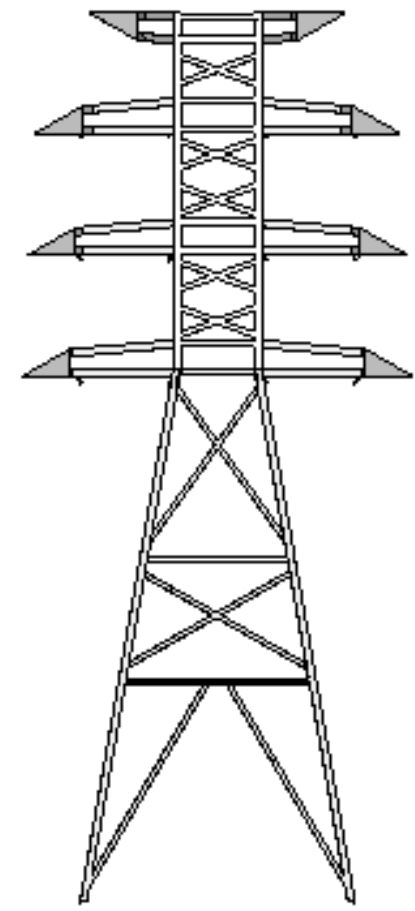

Gambar 4. Pemodelan Tower Transmisi

Setelah pemodelan tower transmisi, langkah selanjutnya adalah pemodelan isolator $500 \mathrm{kV}$. Pemodelan batang konduktor menggunakan material epoxy resin. Hasil pemodelan batang konduktor dalam isolator dapat dilihat pada gambar 5 .

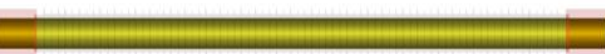

Gambar 5. Pemodelan Batang Konduktor dalam Isolator

Pemodelan selanjutnya adalah memasang sirip-sirip isolator dengan material polymide dan memasang end fitting dengan material iron. Hasil pemodelan isolator dapat dilihat pada gambar 6.

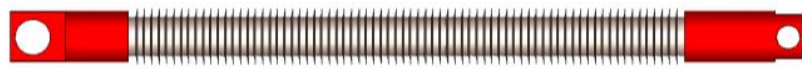

Gambar 6. Pemodelan Isolator
Setelah pemodelan isolator selesai, kita lakukan pemasangan isolator pada suspensi isolator. Dari hasil pemodelan kita dapatkan hasil yang ditunjukkan pada gambar 7.

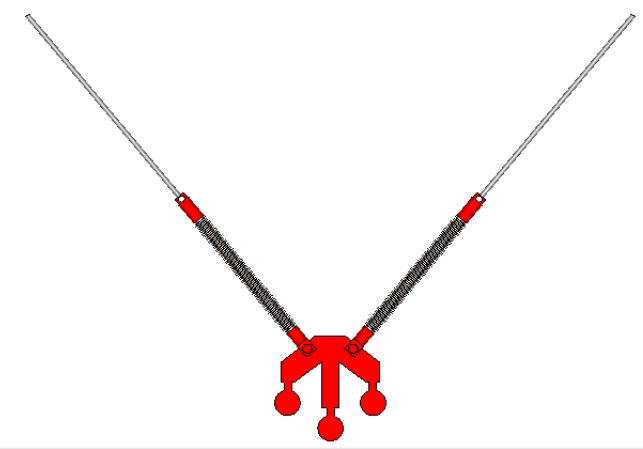

Gambar 7. Pemodelan Isolator dengan Suspensi

Dan Pemodelan manusia dapat dilihat pada gambar 8.

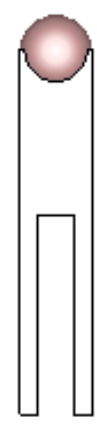

Gambar 8. Pemodelan Manusia

\section{E. Material Penyusun Tower Transmisi, Isolator Polimer, dan Manusia}

Tabel berikut menunjukan material-material yang digunakan oleh tower transmisi, dan isolator polimer pada simulasi berdasarkan pada data library CST Studio Suite.

Tabel 1.

Data Sheet Material Tower Transmisi dan Konduktor

\begin{tabular}{clcc}
\hline \multirow{2}{*}{ No } & & \multicolumn{2}{c}{ Material } \\
& & Copper (Pure) & Ferro A6M (lossy) \\
\hline 1 & Epsilon & 1 & 5.9 \\
2 & Mue & 1 & 1 \\
3 & El. Cond. (S/m) & $5.96 \times 10^{7}$ & 2 \\
4 & Therm. Cond. (W/K/m) & & 2 \\
\hline \hline
\end{tabular}

Tabel 2.

Data Sheet Material Isolator

\begin{tabular}{clcc}
\hline \hline \multirow{2}{*}{ No } & \multicolumn{1}{c}{ Unit } & \multicolumn{2}{c}{ Material } \\
& & Epoxy Resin & Polymide (lossy) \\
\hline 1 & Epsilon & 4 & 3.5 \\
2 & Mue & 1 & 1 \\
3 & El. Cond. (S/m) & $1 \times 10^{-15}$ & \\
4 & Rho $\left(\mathrm{kg} / \mathrm{m}^{3}\right)$ & 1500 & 1400 \\
5 & Therm. Cond. $(\mathrm{W} / \mathrm{K} / \mathrm{m})$ & 0.2 & 0.2 \\
6 & Heat cap. $(\mathrm{kJ} / \mathrm{K} / \mathrm{kg})$ & & $1.42857 \times 10^{-7}$ \\
7 & Diffusivity (m $\left.{ }^{2 /} / \mathrm{s}\right)$ & & 2.5 \\
8 & Young's Mod. $(\mathrm{GPa})$ & 13 & 0.4 \\
9 & Poiss. Ratio & 0.45 & 25 \\
10 & Thermal Exp. $\left(1 \mathrm{e}^{-6} / \mathrm{K}\right)$ & & \\
\hline \hline
\end{tabular}


Tabel 3.

Data Sheet Material Manusia

\begin{tabular}{clc}
\hline \hline No & \multicolumn{1}{c}{ Unit } & Material (Heart) \\
\hline 1 & Epsilon & 1 \\
2 & Mue & 1 \\
3 & Rho $\left(\mathrm{kg} / \mathrm{m}^{3}\right)$ & 1100 \\
4 & Therm. Cond. $(\mathrm{W} / \mathrm{K} / \mathrm{m})$ & 0.293 \\
5 & Heat cap. $(\mathrm{kJ} / \mathrm{K} / \mathrm{kg})$ & 3.5 \\
6 & Diffusivity $\left(\mathrm{m}^{2 /} / \mathrm{s}\right)$ & $7.61039 \mathrm{e} \times 10^{-8}$ \\
7 & Bloodflow $\left(\mathrm{W} / \mathrm{K} / \mathrm{m}^{3}\right)$ & 9100 \\
8 & Metab. Rate $\left(\mathrm{W} / \mathrm{m}^{3}\right)$ & 1620 \\
\hline \hline
\end{tabular}

\section{F. Simulasi Saluran Transmisi}

Tegangan yang bekerja pada saluran transmisi sesuai dengan tegangan nominal saluran transmisi, yaitu $500 \mathrm{kV}$. Gambar 9 menunjukan tegangan yang diberikan pada saluran transmisi tersebut. Tegangan $500 \mathrm{kV} 3$ fasa diberikan pada konduktor yang berwarna merah pada gambar dengan penempatan $R, S$ dan $T$.

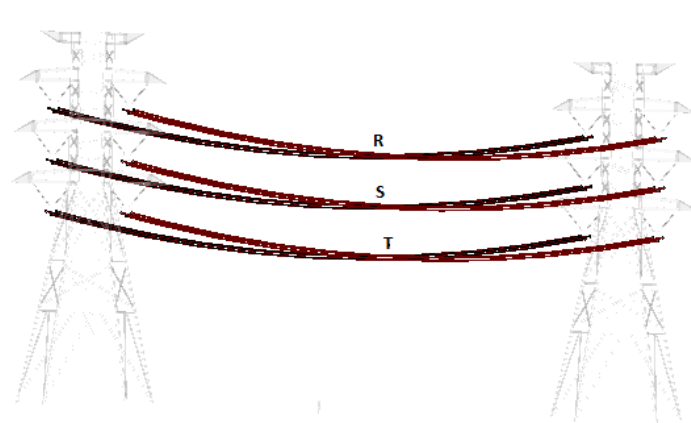

Gambar 9. Tegangan Kerja Saluran Transmisi

\section{HASIL SIMULASI DAN ANALISIS DATA}

\section{A. Hasil Simulasi pada Saluran Transmisi}

Pada gambar 10, dapat dilihat distribusi medan magnet pada saluran transmisi dengan indikator warna. Warna merah pada gambar menunjukkan nilai medan magnet tertinggi dan warna biru bernilai sedikit atau tidak ada nilai medan magnetnya. Pada gambar a dan $b$ menunjukkan nilai distribusi medan magnet di tengah-tengah saluran transmisi.

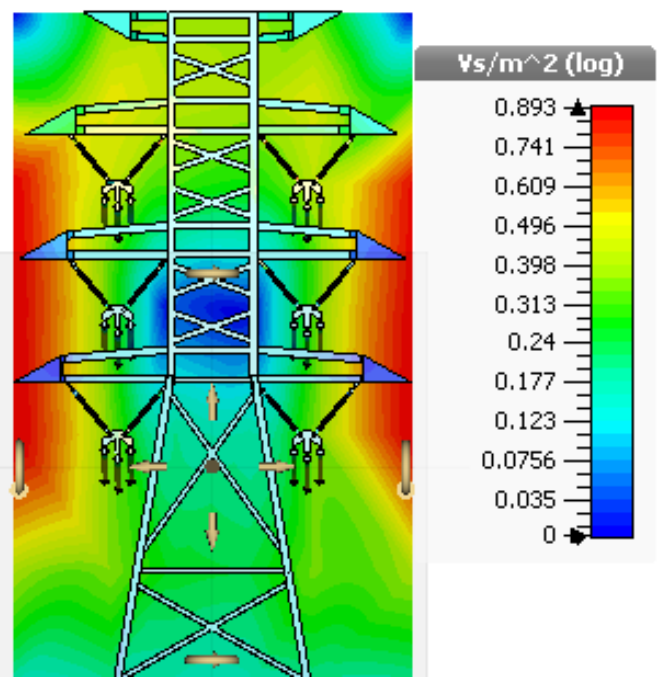

(a)

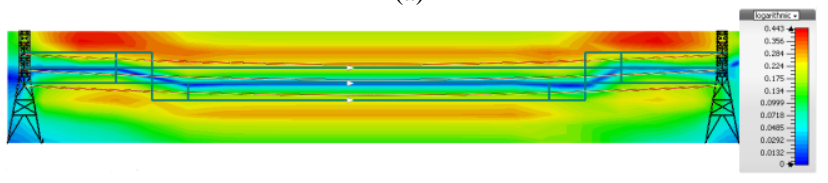

(b)

Gambar 10. Distribusi Medan Magnet di Saluran Transmisi, (a) Tampak Depan (b) Tampak Samping

\section{B. Analisis Medan Magnet pada Tower}

Nilai medan magnet pada tower mengalami naik turun. Pada titik awal peningkatan konstan, lalu pada titik 23 mengalami peningkatan yang signifikan dan nilai tertinggi ada pada ketinggian $39,31 \mathrm{~m}$ yang bernilai $0,83 \mathrm{Vs} / \mathrm{m}^{2}$, lalu turun hingga titik 60 .
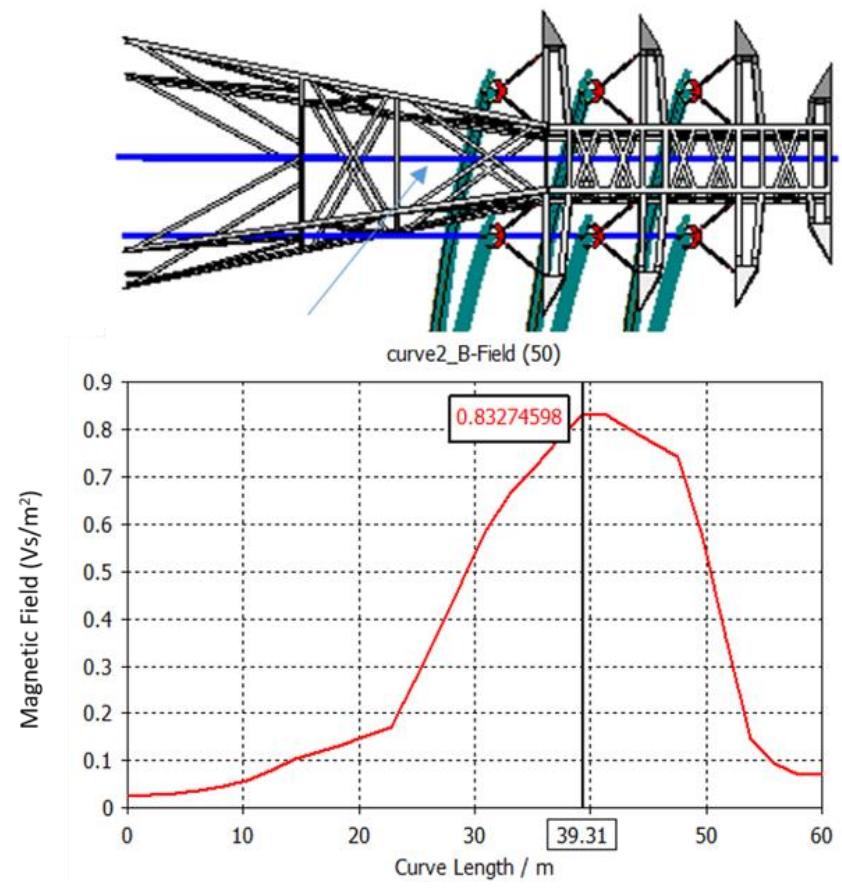

Gambar 11. Grafik Medan Magnet pada Tower

\section{Analisis Medan Magnet pada Phase $R, S$, dan $T$}

Dapat dilihat digambar 12 nilai medan magnet pada saluran transmisi di phase T dengan tinggi kurva $30 \mathrm{~m}$. Garis berwarna biru menunjukkan tinggi dari kurva tersebut. Pada titik T nilai medan magnet adalah $0,17 \mathrm{Vs} / \mathrm{m}^{2}$ dan mengalami peningkatan hingga titik R. Pada titik S dengan tinggi $38 \mathrm{~m}$ bernilai $0,21 \mathrm{Vs} / \mathrm{m}^{2}$. Dan pada titik $\mathrm{R}$ dengan tinggi $46 \mathrm{~m}$ bernilai $0,35 \mathrm{Vs} / \mathrm{m}^{2}$ 


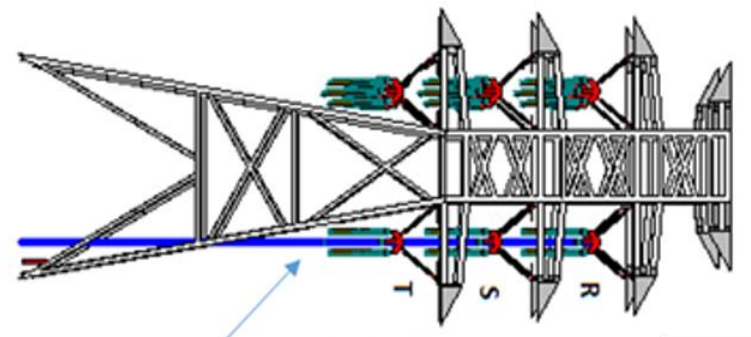

curve3_B-Field (50)

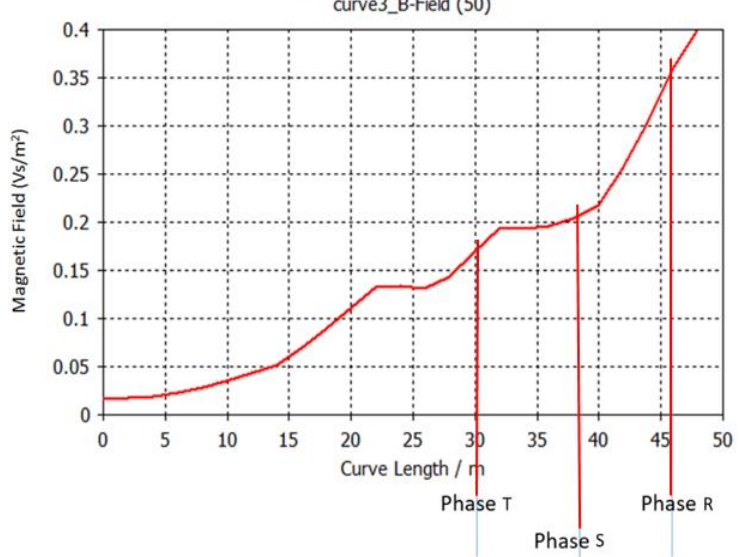

Gambar 12. Grafik Medan Magnet pada Phase R, S, dan T

D. Analisis Medan Magnet pada Konduktor (Jarak Terendah) dan Manusia

Nilai medan magnet di konduktor saluran transmisi mengalami kenaikan dan sedikit penurunan. Gambar 13 pada manusia dengan ketinggian 0 - 2,2 m terlihat garis kurva mengalami sedikit kenaikan dengan nilai medan magnet ratarata $0,025 \mathrm{Vs} / \mathrm{m}^{2}$, lalu pada ketinggian $10 \mathrm{~m}$ mengalami kenaikan yang drastis hingga pada titik puncak di tepi konduktor yaitu di ketinggian $23 \mathrm{~m}$ yang bernilai 0,328 $\mathrm{Vs} / \mathrm{m}^{2}$. Lalu pada konduktornya sendiri mengalami penurunan, ini dikarenakan medan magnet terkuat adalah di sekitar konduktor maka di konduktornya sendiri nilai medan magnet kecil dibandingkan sekitarnya. Pada gambar 4.13 menunjukkan nilai medan magnet pada manusia yaitu sebesar $0,0187 \mathrm{Vs} / \mathrm{m}^{2}$.

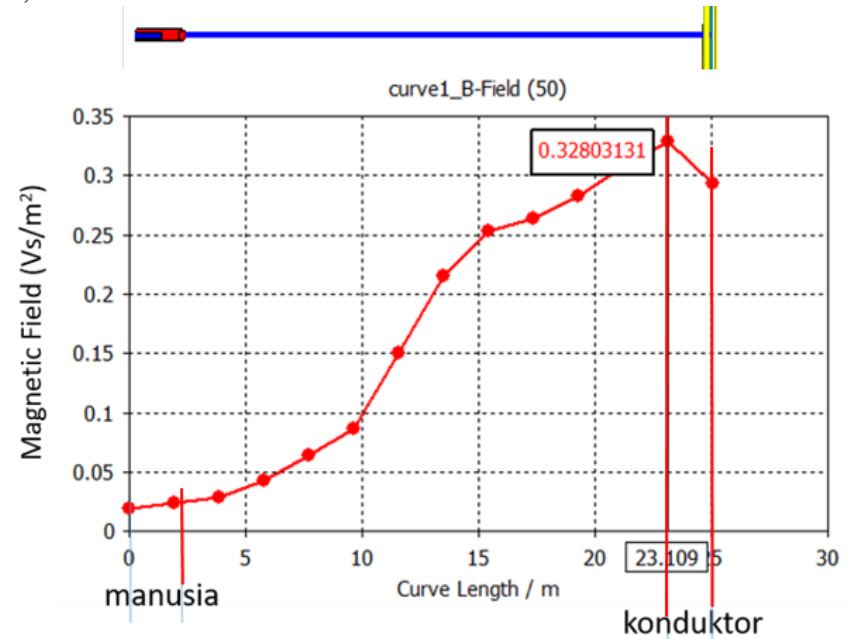

Gambar 13. Perbandingan medan listrik pada sirip isolator dengan keretakan

\section{E. Perbandingan Medan Magnet pada Manusia di Bawah Saluran Transmisi}

Dalam bahasan ini, akan dilakukan perbandingan antar manusia dengan jarak masing-masing $30 \mathrm{~m}$ pada sepanjang saluran transmisi. Pada gambar 4.16 dapat dilihat nilai medan magnet pada jarak $0 \mathrm{~m}$ dari tower mengalami peningkatan hingga jarak $120 \mathrm{~m}$, lalu dari jarak $120 \mathrm{~m}$ hingga 180 hampir konstan di $0,06 \mathrm{Vs} / \mathrm{m}^{2}$. Ini menandakan bahwa nilai medan magnet terbesar yaitu $0,06 \mathrm{Vs} / \mathrm{m}^{2}$ terletak di tengah saluran transmisi atau di bawah konduktor (jarak terendah).

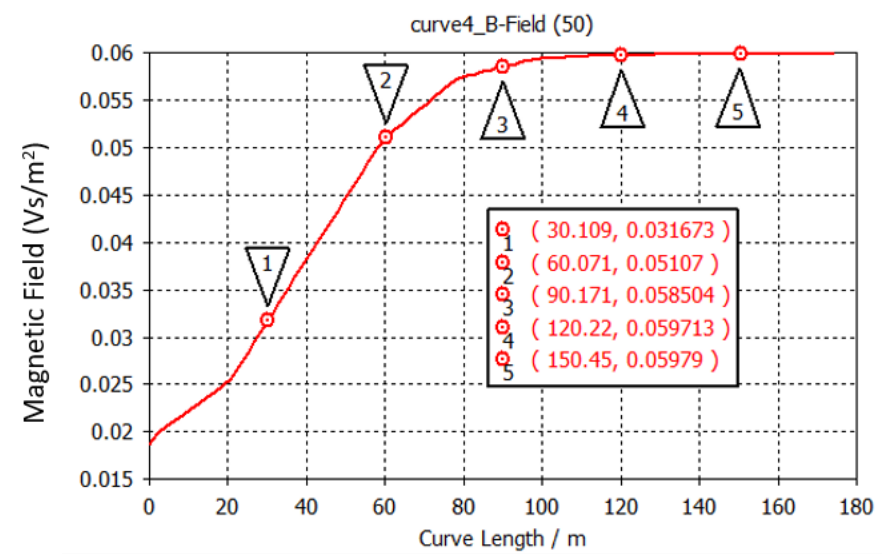

Gambar 15. Grafik Medan Magnet pada Manusia di Bawah Saluran Transmisi

\section{F. Perbandingan Pengukuran Langsung dengan Hasil Simulasi}

Setelah mendapatkan hasil kurva dan grafik dari simulasi If solver dalam software CST Studio Suite, langkah selanjutnya adalah melakukan pengukuran langsung di saluran transmisi $500 \mathrm{kV}$. Pengukuran dilakukan di saluran transmisi $500 \mathrm{kV}$ krian - gresik yang melewati Surabaya tepatnya di Surabaya bagian barat. Pengukuran langsung dilakukan dengan menggunakan alat ukur medan magnet ELF Field Strength Measurement System produksi Holaday Industries Inc. dengan tipe alat ukur HI-3604.

Langkah pertama pengukuran langsung medan magnet adalah mengukur jarak yang akan diukur. Jarak pengukuran disesuaikan dengan jarak yang ada di pemodelan simulasi saluran transmisi. Setelah mendapatkan nilai-nilai medan magnet pada titik-titik yang sudah ditentukan dengan menggunakan simulasi lf solver dalam software CST Studio suite dan pengukuran langsung di Gardu Induk Driyorejo, kita dapat membandingkan nilai-nilai medan magnet tersebut menggunakan grafik. Berikut hasil perbandingan simulasi dengan pengukuran ditunjukkan di tabel 4.

Tabel 4.

Perbandingan Hasil Simulasi dengan Pengukuran

\begin{tabular}{rrr}
\hline \hline \multicolumn{1}{c}{$\begin{array}{c}\text { Jarak } \\
\text { (meter) }\end{array}$} & Hasil Simulasi $\left(\mathrm{Vs} / \mathrm{m}^{2}\right)$ & \multicolumn{2}{c}{$\begin{array}{c}\text { Pengukuran } \\
\left(\mathrm{Vs} / \mathrm{m}^{2}\right)\end{array}$} \\
\hline 0 & 0,018 & 0,02 \\
30 & 0,031 & 0,035 \\
60 & 0,051 & 0,038 \\
90 & 0,058 & 0,034 \\
120 & 0,059 & 0,048 \\
150 & 0,059 & 0,043 \\
180 & 0,06 & 0,05 \\
\hline \hline
\end{tabular}

\section{KESIMPULAN}

Nilai medan magnet terbesar pada saluran transmisi terletak di bagian samping kanan dan kiri dari menara transmisi yaitu sebesar $0,83 \mathrm{Vs} / \mathrm{m}^{2}$ dan yang terkecil terletak pada manusia yang berada di bawah konduktor yaitu sebesar $0,0187 \mathrm{Vs} / \mathrm{m}^{2}$. Hal ini dikarenakan faktor penyusun bahan dan konduktifitas termal bahan, sehingga mengakibatkan efek polarisasi antar muka makroskofis (macroscopic 
interface) yang dapat memperburuk sifat dielektrik bahan. Bahan steel pada menara transmisi menunjukkan nilai medan magnet yang lebih tinggi dibandingkan lainnya.

Pada simulasi terhadap operator (manusia) di bawah saluran transmisi didapatkan hasil bahwa nilai rata - rata yang terdapat di simulasi adalah $0,048 \mathrm{Vs} / \mathrm{m}^{2}$, ini mengartikan bahwa manusia yang berada di sekitar tower transmisi melebihi ambang batas aman untuk intensitas medan magnet, karena batasan untuk manusia adalah $0,025 \mathrm{Vs} / \mathrm{m}^{2}$ berdasarkan SNI 04-6950-2003. Dan ini akan berdampak jangka panjang terhadap kesehatan manusia.

Dari hasil perbandingan dapat dilihat nilai pengukuran langsung dengan simulasi tidak berbeda jauh. Nilai medan magnet berada dititik tertingginya pada saat 180 meter yang terletak di tengah saluran transmisi atau tepat di bawah konduktor dengan jarak terendah yaitu sebesar $0,06 \mathrm{Vs} / \mathrm{m}^{2}$ pada hasil simulasi dan $0,05 \mathrm{Vs} / \mathrm{m}^{2}$ pada hasil pengukuran.

\section{DAFTAR PUSTAKA}

[1] Tobing, Bonggas L., 2003, "Dasar Teknik Pengujian Tegangan Tinggi," Jakarta: PT Gramedia Pustaka Utama.

[2] Vassiliki T. Kontargyri, Ioannis F. Gonos, Ioannis A. Stathopoulos, and Alex M.Michaelides, "Simulation of the Electric Field on High Voltage Insulators using the Finite Element Method", IEEE 2006.

[3] Sani Ugustra, "Kajian Kuat Medan Listrik Pada Konfigurasi Vertikal Saluran Transmisi 150kV”, 2015

[4] SPLN 121, "Konstruksi Saluran Udara Tegangan Tinggi 70 KV dan 150KV dengan Tiang Beton/Baja”, Jakarta, 1996.

[5] Bunmat A., P.Pao-la-or, "Analysis of Magnetic Field Effects Operators Working a Power Transmission Line Using 3D Finite Element Method", Thailand, 2015

[6] Hitoshi Kusuma Putra, "Analisis Pengaruh Medan Listrik Isolator Terhadap Tower Distribusi Saat Terkena Tegangan Tinggi dengan Menggunakan Metode Elemen Hingga”, Institut Teknologi Sepuluh Nopember, 2016.

[7] Hayt William H. And John A. Buck, "Elektromagnetika Edisi Ketujuh”, Penerbit Erlangga, Januari 2006.

[8] Yusrizal Afif, "Analisis Distribusi Medan Listrik Pada Isolator Gantung Bahan Polimer Menggunakan Finite Element Method”, Institut Teknologi Sepuluh November, 2014. 